\title{
Evaluation of a rapid enzyme immunoassay test for diagnosis of contamination of milk, water and feces to Salmonella Typhimurium
}

\author{
Mohammad Khosravi ${ }^{1 *}$, Darioush Gharibi', Najmeh Moradi², and Masood Ghorbanpoor ${ }^{1}$ \\ ${ }^{1}$ Department of Pathobiology, Faculty of Veterinary Medicine, Shahid Chamran University of Ahvaz, Iran \\ ${ }^{2}$ Graduated Student, Faculty of Veterinary Medicine, Shahid Chamran University of Ahvaz, Iran
}

\begin{abstract}
KHOSRAVI, M., D. GHARIBI, N. MORADI, M. GHORBANPOOR: Evaluation of a rapid enzyme immunoassay test for diagnosis of contamination of milk, water and feces to Salmonella Typhimurium. Vet. arhiv 90, 509-516, 2020.
\end{abstract}

\section{ABSTRACT}

Serology-based detection methods have more applicable characteristics than standard bacterial culture methods. The aim of this study was to evaluate a cost-efficient, rapid, sensitive and simple test to diagnose milk, water and feces contaminated with Salmonella enteric subsp. enterica serovar Typhimurium ( $S$. Typhimurium). The method developed was based on the addition of HRP-conjugated anti-Salmonella antibodies to the sample, precipitation of the complexes formed using centrifuge, and evaluation of the peroxidase activity of the sample supernatants. Raw cow's milk, water and cattle feces samples were spiked with seven concentrations of $S$. Typhimurium. The optimized test recorded an accurate volume and concentration of HRP-conjugated antibodies, the bacteria, samples, ionic compounds and the precise time of the reaction. Also, the method of the test and standard sample preparation were carefully optimized. The tests were repeated at least ten times, and the minimum level of detectable bacteria was determined for each repetition. The results obtained were compared with the conventional bacterial culture method. The results showed that in an optimal condition, conjugated anti-Salmonella antibodies interacted with the bacteria in any matrix. The developed method can detect at least $30,30,3 \times 10^{3}$, and $3 \times 10^{3} \mathrm{cell} / \mathrm{mL}$ of $S$. Typhimurium in water, PBS, milk and feces samples respectively, in less than 20 minutes. Also, antibody detection using this EIA can detect an antibody concentration range of $4.3-70 \mu \mathrm{g} / \mathrm{mL}$. The developed method is a rapid, cost-efficient and simple assay, and can be used to detect $S$. Typhimurium in various samples.

Key words: EIA; Salmonella Typhimurium; water; milk; feces

\section{Introduction}

Enzyme immunoassay (EIA) involves all methods that detect the antigen-antibody reaction by using enzyme conjugation and enzyme substrate. ENGVALL and PERLMANN developed the ELISA method for the first time in 1971 to determine the IgG level in rabbit serum. Today, EIA methods are

used routinely for research and diagnostic tests all around the world. One of the more commonly used EIA techniques is the heterogeneous enzymatic immunoassay method (LEQUIN, 2005). In Enzyme Linked Immunosorbent Assay (ELISA), the antigenantibody complexes are bound to microplate wells,

\footnotetext{
*Corresponding author:

Khosravi Mohammad, Faculty of Veterinary Medicine, Shahid Chamran University of Ahvaz, Khuzestan, Iran, Phone: +98 93 7621 1901; E-mail: m.khosravi@scu.ac.ir
} 
and undesired elements are removed from the reaction through washing steps. ELISA can prepare qualitative or quantitative results based on the use of standard samples and spectrophotometric devices. Various types of ELISA have been developed by modification of the basic steps (GAN and PATEL, 2013). Researchers always use ELISA for its capacity for sensitive detection of peptide and protein in biological samples.

Salmonella species (spp.) infect human and animal species all around the world. Despite the various activities carried out for prevention and treatment of salmonellosis, it causes massive economic losses in industrial and developing countries (CRUMP et al., 2004). Diarrhea, fever, abdominal cramps, and vomiting are the most common signs of salmonellosis (MAJOWICZ et al., 2010). The causative agent spreads through fecal-oral transmission and consumption of raw contaminated animal products (GILLESPIE et al., 2005). There is a great deal of concern due to the presence of antibiotic-resistant strains and large economic losses (CHIU et al., 2002). Early and appropriate identification of the carriers and the contaminated foods are the most important methods to prevent salmonellosis.

Contamination of biological samples with Salmonella spp. can be detected by a wide range of bacteriological, molecular and serological techniques. There are various limitations related to the methodology, such as time and budget, poor sensitivity and the need for well-equipped labs and expert technicians. A sensitive, fast, economical and simple method in this area could resolve these problems. The aim of the current study was to develop a new EIA to detect $S$. Typhimurium in contaminated milk, water and feces. Also, detection of anti-Salmonella Typhimurium antibodies was evaluated using the rapid test developed. This assay tried to avoid the coating, blocking and washing steps, decrease the time needed, and increase the sensitivity of the usual ELISA.

\section{Materials and methods}

Preparation of the bacteria. The Salmonella enteric subsp. Enterica, serovar Typhimurium (ATCC14028), was cultured in blood agar media and incubated at $37^{\circ} \mathrm{C}$ for at least 24 hours. A bacterial suspension was prepared in sterile phosphate buffer saline (PBS), and its OD 600 was adjusted to 0.12 . Seven 10-fold serial dilutions of tested suspension were prepared in sterile PBS. The bacterial counting of the prepared suspensions was done using a standard colony counting method (MARKEY et al. 2013). The bacterial suspensions were inactivated by the addition of $0.5 \%$ formaldehyde.

Preparation of the standard samples. The standard samples were prepared using experimentally contaminated water, PBS, milk and fecal samples through the following steps: the seven $1: 10$ serial dilutions $\left(10^{-1}-10^{-7}\right)$ of $S$. Typhimurium and a negative control sample were prepared in PBS containing $1 \mathrm{mg} / \mathrm{mL}$ bovine serum albumin (BSA) (Sigma Aldrich Co., Germany). All prepared concentrations of the $S$. Typhimurium were centrifuged and the precipitated bacteria were mixed with some of the individual centrifuged and diluted milk (1/25) and fecal (1/10) samples of centrifuged-undiluted water and PBS samples.

Detection of Salmonella Typhimurium in PBS and water samples. $100 \mu \mathrm{L}$ of the diluted $1 / 5000$ or $1 / 30,000$ (respectively for PBS and water samples) anti- Salmonella HRP-conjugated polyclonal antibodies (Abcam Co., USA) (1 mg/mL) was added to the standard and test samples and final volumes were adjusted to $2.5 \mathrm{~mL}$ using PBS, which contained different concentrations (0 to $100 \mathrm{~mm}$ ) of $\mathrm{CaCl}_{2}, \mathrm{MgCl}_{2}$ and PEG (Merck Co., USA). The prepared samples were shacked at $37{ }^{\circ} \mathrm{C}$ for 5 minutes. Then, the samples were centrifuged for $5 \mathrm{~min}$ at $8000 \mathrm{~g}$. Afterwards, $100 \mu \mathrm{L}$ of the supernatant was placed in micro-titer ELISA plate wells and tetramethyl benzidine (TMB) substrate solution $50 \mu \mathrm{L}$ was added to the samples. The reaction was terminated after $5 \mathrm{~min}$ by adding $50 \mu \mathrm{L}$ $\mathrm{HCl} 2 \mathrm{M}$ (Merck Co., USA) stop solution. Finally, the optical density (OD) was read at $450 \mathrm{~nm}$ using a spectrophotometer (AccuReader, Taiwan).

Detection of Salmonella Typhimurium in milk and fecal samples. Standard samples were prepared by centrifugation of some of the milk and fecal samples in $8000 \mathrm{~g}$ for $5 \mathrm{~min}$, and the liquid layer between the lipid and precipitate was diluted to $1: 10$. Some of the un-centrifuged milk and fecal samples were 
diluted to 1:10 and used as test samples. Detection of the bacterial concentration mentioned, in standard and test samples, was undertaken by addition of 1 $\mathrm{mg} / \mathrm{mL}$ BSA, $50 \mu \mathrm{L}$ PMSF anti-protease (SigmaAldrich Co., Germany) and $100 \mu \mathrm{L}$ of $1 / 5000 \mathrm{HRP}-$ conjugated anti-Salmonella antibodies $(1 \mathrm{mg} / \mathrm{mL})$ to $1 \mathrm{~mL}$ of the diluted samples, and the final volume was adjusted to $2.5 \mathrm{~mL}$ using PBS. In the same way as for detection of the bacteria in PBS, the remained steps were undertaken for quantitative detection of the bacteria. Also, three concentrations of $S$. Typhimurium equal to standard samples 5, 6 and 7 were added separately to three parts of the test samples as an internal control. After optimization of the protocol, ten samples were collected from the veterinary hospital and tested as described above.

Detection of anti-Salmonella Typhimurium antibodies. Preparation of the hyperimmune sera. The use of animals in the experiments was approved by the Animals Ethics Committee (AEC) of the Veterinary Medicine Faculty of Shahid Chamran University, Ahvaz, Iran. The hyperimmune serum was obtained from two rabbits immunized with inactivated $S$. Typhimurium. $0.5 \mathrm{~mL}$ of the inactivated bacteria, at a concentration adjusted to 4 McFarland standards, was mixed with an equivalent amount of Freund's complete adjuvant. The prepared antigens were injected subcutaneously and intramuscularly into each rabbit. The booster antigens were prepared by mixing $0.5 \mathrm{~mL}$ of the inactivated bacteria at a concentration adjusted to 2 McFarland standards, with an equal amount of Freund's incomplete adjuvant; three sets of boosters were injected at two week intervals. The Freund's complete and incomplete adjuvants were purchased from Razi Vaccine and Serum Research Institute, Iran. A micro-agglutination test was used to assess the anti-Salmonella Typhimurium antibody titer for each immunized rabbit. The hyper-immune sera were harvested from the immunized rabbits and stored at $-20{ }^{\circ} \mathrm{C}$. A micro-agglutination test was used to assess the anti-Salmonella Typhimurium titers of the prepared hyperimmune sera (SAREYYUPOGLU et al., 2010).
Isolation and purification of the antibodies. The IgG antibodies were purified by ion exchange chromatography on a DEAE-C column (Sigma, Number: D3764) according to the guidelines of HAY and WESTWOOD (2002). Purification of the specific antibodies was done using the following steps: $2 \mathrm{mg} / \mathrm{mL}$ of purified $\mathrm{IgG}$ was mixed with 0.5 $\mathrm{mL}$ of $S$. Typhimurium at a concentration adjusted to $4 \mathrm{McF}$ arland standards, and incubated at $37^{\circ} \mathrm{C}$ for one hour, along with shaking. The antigen-antibody complexes were precipitated by centrifugation for 5 minutes at 10,000 RPM; the resulting sediments were harvested and the supernatant was used for more purification, as in the previous steps. The process was repeated twice and the precipitated complexes were collected together. The precipitates were mixed with $1 \mathrm{~mL}$ of phosphate buffered saline (PBS). The $\mathrm{pH}$ of suspension was adjusted to 3.5 and shaken for 3 minutes. Then the same centrifuge conditions were used for bacterial sedimentation. The supernatant, which contained the specific antibody, was collected and the $\mathrm{pH}$ was adjusted to 7.2. The quantity, purity and titer of the purified antibody were checked by Bradford protein assay, SDS-PAGE and a micro-agglutination test, respectively.

Enzyme immunoassay for detection of antibodies. A 1:2 serial dilution of the affinity purified IgG and negative serums was prepared in PBS, containing $1 \mathrm{mg} / \mathrm{mL}$ BSA. $400 \mu \mathrm{L}$ of bacterial concentration equal to $\mathrm{OD} 0.24$ in $600 \mathrm{~nm}$ and $100 \mu \mathrm{L}$ of 1:10.000 HRP-conjugated anti rabbit IgG (Immuno Chemistry Technologies Co., USA) $(1 \mathrm{mg} / \mathrm{mL})$, was added to each sample. The final volume was adjusted to $2.5 \mathrm{~mL}$ and it was shaken for $5 \mathrm{~min}$ at room temperature. Tubes were centrifuged for 5 min at $8000 \mathrm{~g}$ and $100 \mu \mathrm{L}$ of the supernatant was placed in micro-titer ELISA plate wells. $50 \mu \mathrm{L}$ of TMB substrate was added to the samples and the reaction stopped after $5 \mathrm{~min}$ by adding $50 \mu \mathrm{L} \mathrm{HCL}$ $2 \mathrm{M}$ stop solution. Finally, the optical density was read at $450 \mathrm{~nm}$.

Data analysis. The standard curves coefficients and bacterial concentrations were calculated using Excel software, Ver. 13. 


\section{Results}

Bacterial counting. Counting of the bacterial culture of $\mathrm{OD}=0.12$ revealed the presence of approximately $3 \times 10^{8}$ cell $/ \mathrm{mL}$ in the initial concentration of the bacterial solution; this number was equal to McFarland 1.

Evaluation of the hyper-immune serum. The rabbits produced an appropriate antibody titer after three sets of immunization. The hyper-immune sera had a higher antibody titer (1024) than purified IgG and affinity purified antibodies (612) in the microagglutination test. The SDS-PAGE and Bradford analysis showed appropriate purification of the antibody, using ion-exchange chromatography and affinity purification.

Detection of the bacteria in PBS, water, milk and feces samples. The initial concentration of the Salmonella Typhimurium had an optical density equal to 0.12 at $600 \mathrm{~nm}$ in the supernatant. Seven 1:10 serial dilutions of this concentration were used to prepare the standard samples. Detection of this concentration was obtained by adding $1 \mathrm{mg} / \mathrm{mL}$ BSA, 1/5000 HRP-conjugated anti-Salmonella antibodies $(1 \mathrm{mg} / \mathrm{mL})$ to PBS in a final volume of $2.5 \mathrm{~mL}$. This optimized condition resulted in a reduction in $\mathrm{OD}$, in accordance with the elevation of the bacterial concentration in the PBS, milk, water and stool samples. It is worth mentioning that, unlike the $1 \mathrm{mg} / \mathrm{mL}$ BSA, the use of different compounds, such as $\mathrm{CaCl}_{2}, \mathrm{MgCl}_{2}$ and $\mathrm{PEG}$ in different volumes and concentrations, had no effect on the test. The obtained standard diagram for detection of $S$. Typhimuriumin PBS, water, milk and stool samples using developed rapid ELISA had a coefficient equal to $\mathrm{R}^{2}=0.973,0.983,0.938$ and 0.958 , respectively (Fig. 1). The EIA method developed detected at least $30,30,3 \times 10^{3}$, and $3 \times 10^{3} \mathrm{cel} 1 / \mathrm{mL}$ of $S$. Typhimurium in experimentally contaminated water, PBS, milk and feces samples respectively, in less than 20 minutes.

The results of the experimentally polluted feces sample are presented in Table 1 as internal controls 1,2 and 3. According to the obtained optical densities and the standard curve equation, the relevant concentration of the bacteria could be successfully calculated in the feces sample. After optimization of the methods, stool samples were taken from 10 cases referred to the faculty of the
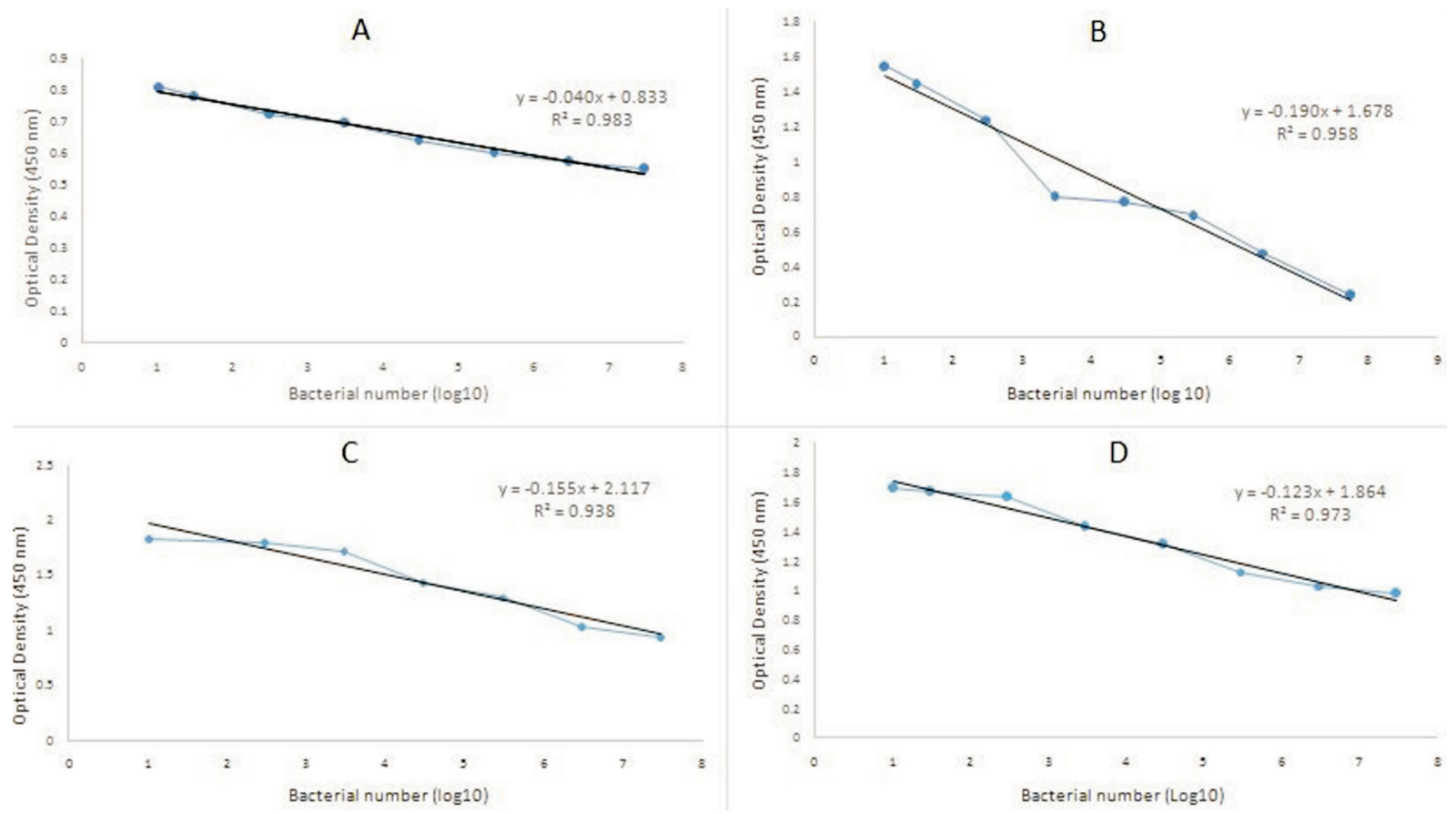

Fig. 1. Standard curves for detection of the Salmonella Typhimurium in experimentally polluted (A) water, (B) feces, (C) milk and (D) PBS samples 
veterinary hospital of Shahid Chamran University of Ahvaz. These samples were immediately sent to the immunology laboratory The EIA test we developed was performed in accordance with the methods described above. All tested samples produced negative results on the bacterial culture; the EIA resulted in the same negative results for all the tested fecal samples, as mentioned for clinical sample 1 in Table 1.

Table 1. Optical density (OD) of the developed enzyme immune assay for detection of various concentrations of the Salmonella Typhimurium in feces samples

\begin{tabular}{|l|c|c|}
\hline \multirow{2}{*}{$\begin{array}{l}\text { Bacterial number } \\
(\log 10)\end{array}$} & \multicolumn{2}{|c|}{ OD $(450 \mathrm{~nm})$} \\
\cline { 2 - 3 } & Fecal samples & Clinical feces sample \\
\hline 7.47 & 0.237 & 0.627 \\
\hline 6.47 & 0.475 & 0.931 \\
\hline 5.47 & 0.695 & 0.968 \\
\hline 4.47 & 0.773 & 1.068 \\
\hline 3.47 & 0.801 & 1.155 \\
\hline 2.47 & 1.242 & 1.23 \\
\hline 1.47 & 1.448 & 1.258 \\
\hline 1 & 1.553 & 1.245 \\
\hline Clinical sample 1 & & 1.301 \\
\hline Internal control 1 & 1.21 & \\
\hline Internal control 2 & 1.321 & \\
\hline Internal control 3 & 1.404 & \\
\hline
\end{tabular}

Table 2. Optical density (OD) in the rapid enzyme immune assay developed for detection of the anti-

Salmonella Typhimurium antibody in serum

\begin{tabular}{|l|c|}
\hline Antibody concentration $(\mu \mathrm{g} / \mathrm{mL})$ & OD $(450 \mathrm{~nm})$ \\
\hline 70 & 0.102 \\
\hline 35 & 0.255 \\
\hline 17.5 & 0.383 \\
\hline 8.75 & 0.52 \\
\hline 4.37 & 0.615 \\
\hline Negative sample & 1.677 \\
\hline
\end{tabular}

Detection of the anti-Salmonella Typhimurium antibodies. Successful detection of the antibody levels was achieved by adding albumin $1 \mathrm{mg} / \mathrm{mL}$, HRP-conjugated anti-rabbit antibodies (1/10.000), and a bacterial concentration equal to OD 0.24 in $600 \mathrm{~nm}$. This optimized condition resulted in a decrease in optical density in accordance with the increase in specific anti-Salmonella Typhimurium IgG concentration; this optimized condition could successfully detect an antibody concentration range of 4.3-70 $\mu \mathrm{g} / \mathrm{mL}$ in diluted serum samples (Table 2). The diagram obtained for detection of anti $S$. Typhimurium antibodies in standard samples had a coefficient equal to $\mathrm{R}^{2}=0.976$.

\section{Discussion}

This research aimed at evaluation of an EIA method of which does not require antigen coating, blocking and washing steps. The designed method was based on the preparation of the optimal conditions for antibody and bacterial interaction in various textures in the minimum possible time. The [antibody-bacteria] complexes were settled out using simple centrifugation; then, the bacterial concentration in each sample was quantified according to the level of the enzymeconjugated antibodies in the upper parts of the solution. Experimentally contaminated samples were prepared by making 1:10 serial dilutions of $S$. Typhimurium in four matrixes of PBS, water, milk and cattle feces.

Incubation of the antigen-antibody for 5 minutes produced suitable results. The optical densities decreased in all type seven samples in the presence of a small number of bacteria. This method was based on precipitation of the HRP-conjugated antibodiesbacterial complex using centrifuge, which leads to a reduction in the level of the conjugated antibodies in the supernatant parts of the samples; the reduction of the level was in accordance with the bacterial concentration in each sample. Unlike routine ELISA, by which weak antigen-antibody interactions are separated in the washing process (WILSON, 2013), this method can preserve weak antigen-antibody interactions. This could enhance the test sensitivity and decrease its specificity, in comparison to the usual ELISA method. In addition, the test's specificity was improved by decreasing the interaction time of the antigenantibody so that only specific antibodies that have high affinity could react with the target antigens 
in a short incubation time (WILSON, 2013). This modification leads to limitation of the crossing reaction. Overall, combinations of the methods and time of the interactions led tosatisfactory sensitivity and specificity.

The texture of stools and milk samples have a distinctive effect on the antibody-antigen reaction. Due to different feeding, environmental and physiological conditions, each animal has a specific gut microbiome, electrolyte compounds (SHALIT et al., 1991), pH, level of protease enzyme (ANTALIS et al., 2007) and foreign particles in their stools and/ or milk. These factors affect the antigen-antibody reactions.

Removal of the background effects and standard addition are two approaches to resolve these problems (ELLISON et al., 2008). According to previous investigations, preparation of the stool sample dilutions, at least 200 times, and addition of the anti-protease compound, could not solve the background effects. This problem was solved in the current method by using a part of the milk and stool samples for preparation of the standard samples. Removal of probable initial contamination was obtained by implementation of an initial centrifuge. Therefore, standard samples were prepared by adding the desired concentrations of the Salmonella spp. to the centrifuged samples. This method may only be applicable in preparation of standard samples for detection of the particulate elements such as bacteria. The evaluated method was 100 times more sensitive for $S$. Typhimurium detection in PBS and water than in milk and feces samples; the effects of the matrixes and sample components on antibody-antigen interactions, peroxidase inhibitors or peroxidase activity of the milk and feces samples are the possible reasons for this.

Increasing the ionic strength could decrease the antigens-antibodies interaction in the brief incubation time. The Zeta potential of bacteria is often reduced by the addition of the compounds with low ionic strength, such as bovine serum albumin (ARMSTRONG, 2008; REVERBERI and REVERBERI, 2007). The ionic strength of the current antibody-bacterial interactions was changed by adding ionic compounds such as $\mathrm{CaCl}_{2}$, $\mathrm{MgCl}_{2}$ and poly ethylene glycol (PEG), or using deionized water instead of PBS. In this case, these modifications led to a reduction in the standard curve coefficient.

Salmonella spp. is able to replicate rapidly in clinical samples, thus, detection of the initial levels of the bacteria is faulty in terms of the quantities of the results, but it has been proposed to transfer the samples to an ice-pack. Unlike the current method which evaluates and reports sensitivity on the basis of the real amount of the bacteria, other methods often employ an initial incubation time to increase the sensitivity of the test (KUMAR et al., 2008; MANSFIELD and FORSYTHE, 2000).

Today, different methods are commercially available to detect the bacterial contamination in biological samples, such as polymerase chain reaction, ELISA and the agglutination test. Previously, the sensitivity of these methods was evaluated for detection of Salmonella spp. infection. An indirect competitive ELISA (ICELISA) had a detection limit equal to $10^{6}$ cell/ $\mathrm{mL}$ for detection of $S$. Typhimurium (BANG et al., 2012). Surface plasmon resonance was used for detection of $S$. Typhimurium by BARLEN et al., (2007). This method detected $2.5 \times 10^{5}$ cell/ $\mathrm{mL}$ of bacteria in milk samples. In this regard, MANSFIELD and FORSYTHE, (2000) incubated 6 strains of Salmonella spp. in an enriched culture medium overnight. The bacteria were separated using immunomagnetic beads and detected using a monoclonal antibody in 3 hours. This combined method of immunomagnetic beads and ELISA was able to detect at least $10^{5}-10^{6}$ cell $/ \mathrm{mL}$. Also, an improved ELISA had the ability to identify $5 \times 10^{4}$ cell $/ \mathrm{mL}$ of $S$. Typhimurium in 24 hours (PRUSAKSOCHACZEWSKI et al., 1989).

Appling enrichment media for 10 hours improved the sensitivity of the sandwich ELISA to detect $S$. Typhimurium in milk and food products from $10^{4}-10^{5}$ to 100 cell $/ \mathrm{mL}$; elongation of the enrichment time to 24 hours increased the test sensitivity to 2 cell/mL (KUMAR et al., 2008). In other research, a culture in MRSV medium and detection by the latex agglutination test were used to identify Salmonella spp. The researchers reported sensitivity and specificity as 89 and $100 \%$, respectively (GELINSKI et al., 2002). The immune-chromatography strip method is able to detect $S$. Typhimurium in 10 minutes; the strip 
could detect $1.25 \times 10^{5}$ and $1.25 \times 10^{6}$ cell $/ \mathrm{mL}$ of bacteria in PBS and milk samples, respectively (WANG et al., 2015). Also, WANG et al., (2018), using immunomagnetic beads and qualitative PCR, reported a detection limit of $18 \mathrm{cell} / \mathrm{mL}$ of Salmonella spp. from pork and milk samples in 10 hours. The Real-Time PCR method was used for detection of the $S$. Typhimurium infection; various detection limits 1 to 300 cell $/ \mathrm{mL}$ were reported by researchers (RASTEGAR et al., 2013; DING et al., 2017). However, the current method has a detection limit of $3 \times 10^{3}$ cell $/ \mathrm{mL}$ in fecal samples, 30 cell/ $\mathrm{mL}$ in PBS and water samples and $3 \times 10^{3}$ cell $/ \mathrm{mL}$ in milk samples. Considering the related studies, the relevant characteristics of the newly-developed method, including the acceptable sensitivity, specificity, time of assay and cost efficiency were confirmed in comparison with the usual ELISA methods.

\section{Conclusions}

This research evaluated an EIA method which does not need antigen coating, blocking and washing steps. The conjugated anti-Salmonella antibodies, in optimal condition, interacted with the bacteria in the tested matrixes. This newly- developed EIA method has detection limits equal to $30,30,3 \times 10^{3}$, and $3 \times 10^{3} \mathrm{cell} / \mathrm{mL}$ of $S$. Typhimurium in water, PBS, milk and feces samples respectively, in less than 20 minutes. In addition, antibody detection using this EIA, is able to detect an antibody concentration range of $4.3-70 \mu \mathrm{g} / \mathrm{mL}$ in diluted serum samples. The advantages of this method include costefficiency, the high speed of obtaining results and easy diagnosis of salmonellosis, especially the acute form.

\section{Conflict of interest}

The authors declare that they have no conflict of interest.

\section{Acknowledgements}

This study was financially supported by the Shahid Chamran University of Ahvaz, under grant number 97/3/02/26247.

\section{References}

ANTALIS, T. M., T. SHEA-DONOHUE, S. N. VOGEL, C. SEARS, A. FASANO (2007): Mechanisms of disease: protease functions in intestinal mucosal pathobiology. Nat Clin. Pract. Gastroentero. Hepatol. 4, 393-402.

DOI: $10.1038 /$ ncpgasthep0846
ARMSTRONG, B. (2008) Antigen-antibody reactions. ISBT Sci Ser. 3, 21-32.

DOI: 10.1111/j.1751-2824.2008.00185.X

BANG, J., S. SHUKLA, Y. KIM, M. Y. KIM (2012): Development of indirect competitive ELISA for the detection of Salmonella Typhimurium. Rom. Biotechol. Lett. 17, 7194-7204.

BARLEN, B., S. D. MAZUMDAR, O. LEZRICH, P. KAMPFER, M. KEUSGEN (2007): Detection of Salmonella by surface plasmon resonance. Sensors. 7, 1427-1446.

DOI: $10.3390 / \mathrm{s} 7081427$

CHIU, C. H., T. L. WU, L. H. SU, C. CHU, J. H. CHIA, A. J. KUO, M. S. CHIEN, T. Y. LIN (2002): The emergence in Taiwan of fluoroquinolone resistance in Salmonella enterica serotype choleraesuis. N. Engl. J. Med. 346, 413419.

DOI: 10.1056/NEJMoa012261

CRUMP, J. A., S. P. LUBY, E. D. MINTZ (2004): The global burden of typhoid fever. Bulletin of the World Health Organization. 82, 346-353.

DING, T.,Y. SUO, Z. ZHANG, D. LIU, X. YE, S. CHEN, Y. ZHAO (2017): A multiplex RT-PCR assay for $S$. aureus, L. monocytogenes, and Salmonella spp. Detection in Raw Milk with Pre-enrichment. Front Microbiol. 8, 989. DOI: 10.3389/fmicb.2017.00989

ELLISON, S. L. R., M. THOMPSON (2008): Standard additions: myth and reality. Analyst. 133, 992-997.

DOI: $10.1039 / \mathrm{b} 717660 \mathrm{k}$

ENGVALL, E., P. PERLMANN (1971): Enzyme-linked immunosorbent assay (ELISA). Quanti- tative assay of immunoglobulin G. Immunochemistry 8, 871-874.

DOI: 10.1016/0019-2791(71)90454-x

GAN. S. D., K. R. PATEL (2013): Enzyme immunoassay and enzyme-linked immunosorbent assay. J. Invest Dermatol. 1, 133(9):e12.

DOI: $10.1038 /$ jid.2013.287

GELINSKI, J. M., G. MARTIN, M. T. DESTRO, M. LANDGRAF, B. D. FRANCO (2002): Rapid detection of Salmonella in foods using a combination of SPRINT ${ }^{\mathrm{TM}}$, MSRV $^{\mathrm{TM}}$ and Salmonella Latex Test ${ }^{\mathrm{TM}}$. Rev. Bras. Cienc. Farm. 38, 315-322.

DOI: $10.1590 / \mathrm{S} 1516-93322002000300007$

GILLESPIE, I. A., S. J. O'BRIEN, G. K. ADAK, L. R. WARD, H. R. SMITH (2005): Foodborne general outbreaks of Salmonella enteritidis phage type 4 infection, England and Wales, 1992- 2002: where are the risks? Epidemiol. Infect. $133,759-801$.

DOI: $10.1017 / \mathrm{S} 0950268805004474$

HAY, F. C., O. M. R. WESTWOOD (2002): Isolation and structure of immunoglobulins. In: Practical Immunology. $4^{\text {th }}$ ed., Wiley-Blackwell Publishing, Malden, USA. pp. $1-39$.

DOI:10.1002/9780470757475.ch1 
LEQUIN, R. M. (2005): Enzyme immunoassay (EIA)/enzymelinked immunosorbent assay (ELISA). Clin. Chem. 51, 2415-2418.

DOI: $10.1373 /$ clinchem.2005.051532

KUMAR, S., K. BALAKRISHNA, H. V. BATRA (2008): Enrichment-ELISA for detection of Salmonella typhi from food and water samples. Biomed. Environment. Sci. 21, 137-143.

DOI: $10.1016 / \mathrm{S} 0895-3988(08) 60019-7$

MAJOWICZ, S. E., J. MUSTO, E. SCALLAN, F. J. ANGULO, M. KIRK, S. J. O'BRIEN, T. F. JONES, A. FAZIL, R. M. HOEKSTRA (2010): The global burden of nontyphoidal Salmonella gastroenteritis. Clin. Infect. Dis. 50, 882-889. DOI: $10.1086 / 650733$

MANSFEILD, L. P., S. J. FORSYTHE (2000): The Detection of Salmonella using a Combined Immunomagnetic Separation and ELISA end-detection Procedure. Lett. Appl. Microbiol. 31, 279-83.

DOI: 10.1046/j.1472-765x.2000.00811.x

MARKEY, B., F. LEONARD, M. ARCHAMBAULT, A. CULLINANE, D. MAGUIRE (2013): Enterobacteriaceae. In: Clinical Veterinary Microbiology. Vol. 1. $2^{\text {nd }}$ ed., pp. 239-274.

PRUSAK-SOCHACZEWSKI, E., J. H. LUONG (1989): An improved ELISA method for the detection of Salmonella Typhimurium. J. Appl. Bacteriol. 66, 127-135. DOI: $10.1111 / \mathrm{j} .1365-2672.1989 . t b 02462 . x$

RASTEGAR, H., H. AHMADI ASHTIANI, K. AFRAZ, M. ANDALIBI, S. HALLAJ NEHSHABOURI, M. AKBARI, H. RASSAM, S. PARVIZI, S. ANJARANI (2013): Detection, isolation and assessment of Salmonella entiritidis in milk by conventional culture methods and real-time PCR in Iran. Am. J. Res. Commun. 1, 81-97.

REVERBERI, R., L. REVERBERI (2007): Factors affecting the antigen-antibody reaction. Blood Transfus. 5, 227.

DOI: $10.2450 / 2007.0047-07$

SAREYYUPOGLU, B., Z. CANTEKIN, H. K. MUSTAK (2010): Investigation of Brucella antibodies in bovine sera by rose Bengal plate test (RBPT), serum agglutination test (SAT), microagglutination test (MAT) and 2-mercaptoethanol - microagglutination (2-ME-MAT) test. Ankara Univ. Vet. Fak. Derg. 57, 157-160.

SHALIT, U., E. MALTZ, N. SILANIKOVE, A. BERMAN (1991): Water, sodium, potassium, and chlorine metabolism of dairy cows at the onset of lactation in hot weather. J Dairy Sci. 74, 1874-1883.

DOI: $10.3168 /$ jds.S0022-0302(91)78353-7

WANG, J., Y. LI, J. CHEN, D. HUA, H. DENG, Z. LIANG, J. HUANG (2018): Rapid detection of food-borne Salmonella contamination using IMBs-qPCR method based on pagC gene. Braz. J. Microbiol. 49, 320-328.

DOI: 10.1016/j.bjm.2017.09.001

WANG, W., L. LIU, S. SONG, L. TANG, H. KUANG, C. H. XU (2015): A Highly Sensitive ELISA and Immunochromatographic Strip for the detection of Samonella Typhimurium in milk samples. Sensors (Basel) J. 15, 5281-5292.

DOI: $10.3390 / \mathrm{s} 150305281$

WILSON, R. (2013): Sensitivity and specificity: twin goals of proteomics assays. Can they be combined? Expert. Rev. Proteomics 10, 135-149.

DOI: $10.1586 /$ epr.13.7

Received: 14 September 2019

Accepted: 25 August 2020

KHOSRAVI, M., D. GHARIBI, N. MORADI, M. GHORBANPOOR: Ocjena brzog imunoenzimnog testa u otkrivanju onečišćenja mlijeka, vode i izmeta bakterijom Salmonella Typhimurium. Vet. arhiv 90, 509-516, 2020.

\section{SAŽETAK}

Serološke dijagnostičke metode znatno su primjenjivije u odnosu na standardne bakteriološke kulture. Cilj ovoga istraživanja bio je ocijeniti ekonomsku isplativost, brzinu, osjetljivost i jednostavnost testa u otkrivanju onečišćenosti mlijeka, vode i izmeta bakterijom Salmonella enteric subsp. enterica serovar Typhimurium $(S$. Typhimurium). Metoda se temelji na dodatku HRP-konjugiranih anti-Salmonella protutijela u uzorku, precipitaciji nastalih kompleksa centrifugom i procjeni peroksidazne aktivnosti supernatanta. Uzorci sirovog kravljeg mlijeka, vode i izmeta goveda inokulirani su sa sedam koncentracija bakterije $S$. Typhimurium. Primjenom optimiziranog testa zabilježeni su precizni podaci o volumenu i koncentraciji HRP-konjugiranih protutijela, bakterija, uzoraka, ionskih spojeva i vremenu reakcije. Test i priprema standardnih uzoraka pažljivo su optimizirani. Test je ponovljen najmanje deset puta i u svakom je ponavljanju određena najmanja razina detektibilnih bakterija te su rezultati uspoređeni s konvencionalnim pretragama kultura. Rezultati su pokazali da su u optimalnim uvjetima konjugirana anti-Salmonella protutijela reagirala s bakterijama u svakom tipu uzoraka. Razvijena metoda može u manje od 20 minuta otkriti barem 30 stanica/mL bakterije $S$. Typhimurium u vodi, 30 stanica/mL u PBS-u, $3 \times 10^{3}$ stanica $/ \mathrm{mL}$ u mlijeku i $3 \times 10^{3}$ stanica/ $\mathrm{mL}$ u izmetu. Također, primjena ove metode mogla bi otkriti koncentraciju protutijela od 4,3 do $70 \mu \mathrm{g} / \mathrm{mL}$. Metoda je brza, jeftina i jednostavna te može otkriti bakteriju $S$. Typhimurium u različitim uzorcima.

Ključne riječi: EIA; Salmonella Typhimurium; voda; mlijeko; izmet 